\title{
Three-Stage Single-Chambered Microbial Fuel Cell Biosensor Inoculated with Exiguobacterium aestuarii YC211 for Continuous Chromium (VI) Measurement
}

\author{
Li-Chun Wu ${ }^{1,+}$, Guey-Horng Wang ${ }^{2,+}$, Teh-Hua Tsai ${ }^{3}$, Shih-Yu Lo ${ }^{4}$, Chiu-Yu Cheng ${ }^{4}$ and \\ Ying-Chien Chung $4, *$ (D) \\ 1 Department of Logistics Engineering, Dongguan Polytechnic, Dongguan City 523808, China; \\ mic.wu@msa.hinet.net \\ 2 Research Center of Natural Cosmeceuticals Engineering, Xiamen Medical College, Xiamen 361008, China; \\ wanggh@livemail.tw \\ 3 Department of Chemical Engineering and Biotechnology, National Taipei University of Technology, \\ Taipei 10608, Taiwan; thtsai@ntut.edu.tw \\ 4 Department of Biological Science and Technology, China University of Science and Technology, \\ Taipei 11581, Taiwan; HBO223080284@gmail.com (S.-Y.L.); cycheng@cc.cust.edu.tw (C.-Y.C.) \\ * Correspondence: ycchung@cc.cust.edu.tw; Tel.: +886-2782-1862; Fax: +886-2786-5456 \\ + These authors contributed equally to this work.
}

Received: 2 March 2019; Accepted: 19 March 2019; Published: 22 March 2019

\begin{abstract}
Chromium (VI) [Cr(VI)] compounds display high toxic, mutagenic, and carcinogenic potential. Biological analysis techniques (e.g., such as enzyme-based or cell-based sensors) have been developed to measure $\mathrm{Cr}(\mathrm{VI})$; however, these biological elements are sensitive to the environment, limited to measuring trace $\mathrm{Cr}(\mathrm{VI})$, and require deployment offsite. In this study, a three-stage single-chambered microbial fuel cell (SCMFC) biosensor inoculated with Exiguobacterium aestuarii YC211 was developed for in situ, real-time, and continuous $\mathrm{Cr}(\mathrm{VI})$ measurement. A negative linear relationship was observed between the $\mathrm{Cr}(\mathrm{VI})$ concentration $(5-30 \mathrm{mg} / \mathrm{L})$ and the voltage output using an SCMFC at 2-min liquid retention time. The theoretical $\mathrm{Cr}(\mathrm{VI})$ measurement range of the system could be extended to $5-90 \mathrm{mg} / \mathrm{L}$ by connecting three separate SCMFCs in series. The three-stage SCMFC biosensor could accurately measure $\mathrm{Cr}(\mathrm{VI})$ concentrations in actual tannery wastewater with low deviations ( $<7 \%)$. After treating the wastewater with the SCMFC, the original inoculated E. aestuarii remained dominant ( $>92.5 \%)$, according to the next-generation sequencing analysis. The stable bacterial community present in the SCMFC favored the reliable performance of the SCMFC biosensor. Thus, the three-stage SCMFC biosensor has potential as an early warning device with wide dynamic range for in situ, real-time, and continuous $\mathrm{Cr}(\mathrm{VI})$ measurement of tannery wastewater.
\end{abstract}

Keywords: biosensor; chromium; microbial fuel cell; wastewater

\section{Introduction}

Hexavalent chromium [Cr(VI)] is a common environmental pollutant, used extensively in numerous industrial processes (e.g., tanning, electroplating, wood preservation, textile dyeing, and ore refining) [1]. Because of its high oxidizing potential, $\mathrm{Cr}(\mathrm{VI})$ easily causes toxic, mutagenic, and carcinogenic effects on biological organisms and has been identified as one of the 17 chemicals posing the greatest threat to humans by the US Environmental Protection Agency [2]. Thus, real-time monitoring and bioremediation of $\mathrm{Cr}(\mathrm{VI})$ are essential to protect human health and the environment. 
To date, various bacterial strains, including Pseudomonas sp., Enterobacter aerogenes, Serratia proteamaculans, Bacillus sp., Microbacterium sp., Trichococcus pasteurii, Desulfovibrio vulgaris, Ochrobactrum sp., Escherichia coli, Shewanella algae, Paenibacillus ferrarius, Exiguobacterium aestuarii, and Stenotrophomonas maltophilia, capable of reducing $\mathrm{Cr}(\mathrm{VI})$ to $\mathrm{Cr}(\mathrm{III})$, have been isolated from various environments under anaerobic or aerobic conditions [3-9]. Although most of these microbes have been isolated, the availability of high selectivity, high reducing power, broad environmental tolerance, and anaerobic $\mathrm{Cr}(\mathrm{VI})$-reducing bacteria is a prerequisite for accurate $\mathrm{Cr}(\mathrm{VI})$ measurement from actual wastewater using microbial fuel cells (MFCs).

Numerous analysis methods have been developed for $\mathrm{Cr}(\mathrm{VI})$ measurement in water samples. Commonly used chemical analysis techniques include atomic absorption spectrometry, inductively coupled plasma mass spectroscopy, ion chromatography, and colorimetric methods based on diphenylcarbazide [10]. These methodologies are effective and sensitive and have low detection limits; however, complicated operating procedures, expensive equipment, and long measurement times often restrict their application, especially for in situ or real-time $\mathrm{Cr}(\mathrm{VI})$ measurement [11]. Recently, biological analysis techniques have been considered for $\mathrm{Cr}(\mathrm{VI})$ measurement. They can compete with the chemical methods because of their simpler operation, cheaper equipment, and shorter measurement periods [7]. These biological analysis techniques include enzyme-based sensors (e.g., those using urease or cytochrome c3) and cell-based sensors (e.g., those using V79 cells, sulfur-oxidizing bacteria, E. aerogenes, or recombinant E. coli) [11-15]. However, these enzymes, cells, and bacterial strains are sensitive to environmental changes; they are often limited to measuring dilute $\mathrm{Cr}(\mathrm{VI})$ concentrations and require deployment offsite under prepared controlled conditions [15].

The MFC is a self-sustaining device that oxidizes organic compounds in anaerobic anodes using electrogenic microbes, transporting electrons through an external circuit to the aerobic cathode, and converts biochemical energy into electrical energy [16]. Almost all studies in the MFC field are focused on electricity generation; however, continued efforts demonstrate increasing interest in making MFCs as biosensors for monitoring water quality parameters such as organic organics, heavy metals, biological oxygen demand (BOD), and volatile fatty acids [17]. MFCs involving $\mathrm{Cr}(\mathrm{VI})$ have been developed for different purposes. In the cathode of an MFC, $\mathrm{Cr}(\mathrm{VI})$ is used as an electron acceptor to be reduced or removed [18], to facilitate electricity production [19], or to detect trace $\mathrm{Cr}(\mathrm{VI})$ concentrations of $0.2-0.7 \mathrm{mg} / \mathrm{L}$ [20] in batch mode. In the anode of an MFC, $\mathrm{Cr}(\mathrm{VI})$ may be used as a toxic compound to cause the voltage to drop in the MFC because of the inhibition of anodic electrogenic bacteria activity. For example, Liu et al. developed a single-chambered MFC (SCMFC) sensor for monitoring $\mathrm{Cr}^{6+}$ shock $(<10 \mathrm{mg} / \mathrm{L})$ [21]. Similarly, Xu et al. developed a flat membrane-based MFC biosensor to monitor voltage changes that occur with toxic $\mathrm{Cr}^{6+}$ concentrations [22]. However, the calibration curve for the $\mathrm{Cr}^{6+}$ measurement was not established for these MFCs. Additionally, $\mathrm{Cr}(\mathrm{VI})$ is used as an electron acceptor in the anode to make the MFC an "actual" biosensor. Wang et al. inoculated Ochrobactrum anthropi $\mathrm{YC} 152$ into an MFC as an early warning device for accurately measuring $\mathrm{Cr}(\mathrm{VI})$ concentrations of $0.0125-5 \mathrm{mg} / \mathrm{L}$ in batch mode [10]. Wu et al. (2017) inoculated E. aestuarii YC211 into an MFC and discovered the operation performance of MFC-based biosensor was not affected by the surrounding environment [7]. MFC-based biosensors can accurately measure $\mathrm{Cr}(\mathrm{VI})$ concentrations of $2.5-60 \mathrm{mg} / \mathrm{L}$ in batch mode [7]. In practice, the concentrations of $\mathrm{Cr}(\mathrm{VI})$ emitted from various processes should be strictly controlled or continuously monitored for sustainable, clean, and green production. MFC-based biosensors inoculated with a single strain have shown higher selectivity and stability compared with those using bacterial consortia; however, such sensors narrow the $\mathrm{Cr}(\mathrm{VI})$ detection range [17].

A multistage MFC possesses unique attributes because the unconsumed substrate from the front MFC flows to the subsequent MFC, where the bacteria can continuously consume residual substrate [23]. Such system was applied as a BOD sensor, and results indicated that a wide range of BOD concentrations were obtained [23]. The present study developed a three-stage SCMFC biosensor to increase the range of $\mathrm{Cr}(\mathrm{VI})$ measurements in continuous mode. In this study, E. aestuarii YC211 was inoculated into the three-stage MFC system to evaluate its feasibility as a biosensor for in situ 
and real-time $\mathrm{Cr}(\mathrm{VI})$ measurements. $\mathrm{Cr}(\mathrm{VI})$ concentrations in leather processing wastewater were also measured using the developed system. To the best of our knowledge, this is the first report of continuous $\mathrm{Cr}(\mathrm{VI})$ measurement in leather processing wastewater using an MFC-based biosensor.

\section{Materials and Methods}

\subsection{Bacterial Strains and Cultivation}

The E. aestuarii YC211 inoculated to MFC were isolated by Wu et al. from the sludge of an electroplating wastewater treatment plant in New Taipei City, Taiwan [7]. A tryptic soy broth (TSB) supplemented with $\mathrm{Na}_{2} \mathrm{Cr}_{2} \mathrm{O}_{7}$, which together are called a TSBCr medium, containing $60 \mathrm{mg} / \mathrm{L}$ of $\mathrm{Cr}(\mathrm{VI})$ was used to cultivate the E. aestuarii $\mathrm{YC} 211$.

\subsection{Construction of the SCMFC}

An SCMFC was constructed to work as the $\mathrm{Cr}(\mathrm{VI})$ biosensor. The SCMFC comprised a $5 \mathrm{~cm} \times 5 \mathrm{~cm} \times 5 \mathrm{~cm}$ acrylic cube (working volume: $64 \mathrm{~mL}$ ) with a surface area of $18 \mathrm{~cm}^{2}$, a graphite felt anode, and a Pt-free air cathode. The air cathode was made from carbon cloth $(30 \mathrm{wt} \%$ PTFE, Fuel Cell Earth, Woburn, MA, SA), and a 50- $\mu$ m microporous layer (MPL) was applied. The MPL was manufactured as previously described [24]. The anode and cathode were connected using an OK wire (silver plated copper wire) through a variable resistor.

The TSBCr medium $(250 \mathrm{~mL}, 60 \mathrm{mg} / \mathrm{L} \mathrm{Cr}(\mathrm{VI}), 1 / 1000 \mathrm{TSB})$ containing $10^{7.2} \mathrm{cfu} / \mathrm{mL}$ E. aestuarii YC211 was placed in a sterile glass bottle and continuously recycled in the SCMFC at $30{ }^{\circ} \mathrm{C}$ with a $2000-\Omega$ resistor using a submersible pump for cell immobilization under anoxic conditions for $10 \mathrm{~d}$ of liquid retention time (LRT) [7]. To maintain anoxic conditions, the feed solution (TSBCr medium) and SCMFC were purged with nitrogen gas before cell immobilization. Each SCMFC had an upper inlet port for medium and wastewater entrance and a lower port for medium and wastewater exit (Figure 1). Two small pores were located on the top of each SCMFC for online detection of $\mathrm{pH}$, ORP, and DO. In this study, the experiment was conducted in two stages. The $\mathrm{Cr}(\mathrm{VI})$ concentration was either measured by an SCMFC in batch operation or by a three-stage SCMFC system in continuous-flow mode (Figure 1). The three-stage SCMFC system connected three single SCMFC in series and operated in continuous mode.

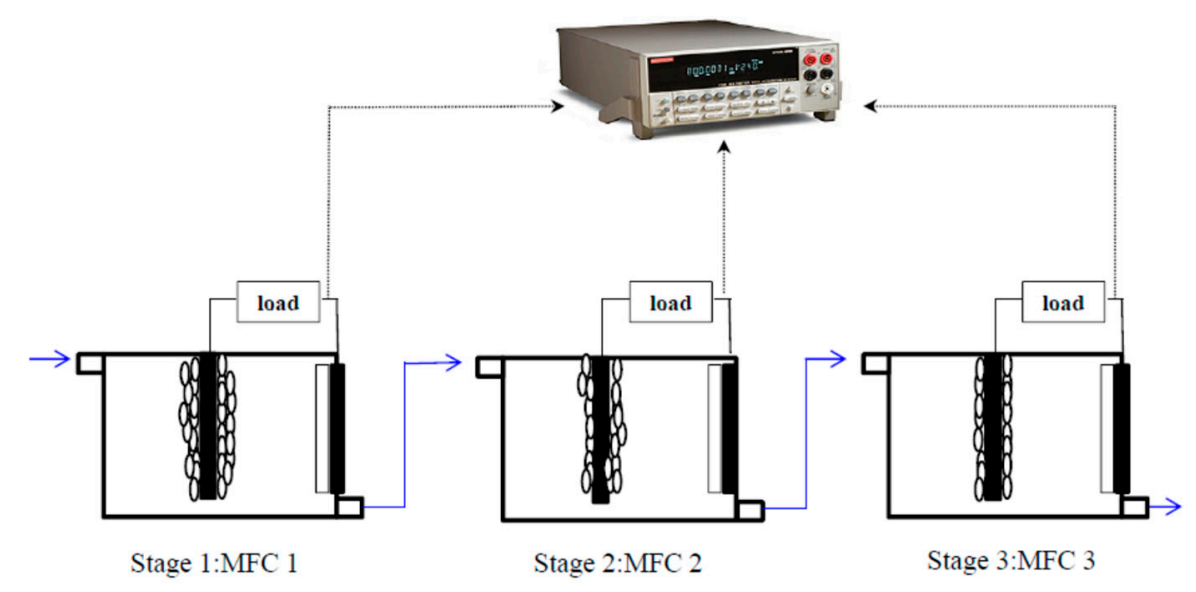

Figure 1. Schematic configuration of three-stage SCMFC system.

\subsection{SCMFC in Batch Operation and Continuous-Flow Operation}

A 1/1000 TSB medium containing $60 \mathrm{mg} / \mathrm{L} \mathrm{Cr}(\mathrm{VI})$ was used as the anolyte to evaluate the performance of the SCMFC in batch operation. The circuit was adjusted using variable resistance $(50-10,000 \Omega)$ to obtain the relationships between the voltage output and current density and between 
the power density and current density of the SCMFC. In this study, the response time was set at $30 \mathrm{~min}$ for each resistance setting.

At the optimal operating resistance of the SCMFC, $\mathrm{Cr}(\mathrm{VI})$ with a final concentration $(0.5-60 \mathrm{mg} / \mathrm{L})$ was added to the $1 / 1000$ TSB medium as the anolyte to obtain an appropriate response time or establish the relationship between the $\mathrm{Cr}(\mathrm{VI})$ concentration and voltage output of the SCMFC biosensor in batch operation. To examine the feasibility of the SCMFC and obtain the standard curve of $\mathrm{Cr}(\mathrm{VI})$ concentration versus voltage of the SCMFC in continuous mode, the anolyte containing various $\mathrm{Cr}(\mathrm{VI})$ concentrations was sequentially and continuously introduced to the SCMFC at 0.5-4 min LRT. The measurement data of the stable voltages of the SCMFC at different inlet $\mathrm{Cr}(\mathrm{VI})$ concentrations were used to create a standard curve.

\subsection{Three-Stage SCMFC in Continuous-Flow Operation}

The anolyte containing different $\mathrm{Cr}(\mathrm{VI})$ concentrations were continuously introduced to the three-stage SCMFC system at $2 \mathrm{~min}$ of LRT. The inlet $\mathrm{Cr}(\mathrm{VI})$ concentrations were divided into three levels. The $45 \mathrm{mg} / \mathrm{L} \mathrm{Cr}(\mathrm{VI})$ medium was first introduced to the system. After $14 \mathrm{~min}$, the $80 \mathrm{mg} / \mathrm{L}$ $\mathrm{Cr}(\mathrm{VI})$ medium was introduced; after $26 \mathrm{~min}$, the $30 \mathrm{mg} / \mathrm{L} \mathrm{Cr}(\mathrm{VI})$ was introduced. The estimated $\mathrm{Cr}(\mathrm{VI})$ concentration was calculated using the stable voltage in each SCMFC based on the established standard curve (described in Section 2.3); subsequently, the estimated $\mathrm{Cr}(\mathrm{VI})$ concentrations of water samples were obtained.

To evaluate the feasibility of the three-stage SCMFC system, actual tannery wastewater samples were collected. Wastewater samples A-H were obtained from the effluents of eight leather processing units. $\mathrm{Cr}(\mathrm{VI})$ concentrations in the actual tannery wastewater were measured using a three-stage SCMFC biosensor and a standard colorimetric method. $\mathrm{Cr}(\mathrm{VI})$ concentrations were measured by the biosensor in continuous-flow operation but by the standard colorimetric method in batch operation. The stable voltage for $\mathrm{Cr}(\mathrm{VI})$ measurement was recorded after $6.6 \mathrm{~min}$ of continuous operation. Two major water quality parameters $\left(\mathrm{BOD}_{5}\right.$ and $\left.\mathrm{DO}\right)$ of the wastewater affecting the voltage production of the SCMFC were determined. To understand the changes in the bacterial community of the SCMFC, the biofilm at the graphite felt was collected for bacterial community analysis through next-generation sequencing (NGS) before and after determining the $\mathrm{Cr}(\mathrm{VI})$ concentration in the tannery wastewater. All of the experiments were conducted using five separate SCMFCs or three groups of three-stage SCMFCs, and each analysis was conducted in triplicate.

\subsection{Analysis}

A specific $\mathrm{Cr}(\mathrm{VI})$ concentration was prepared from $\mathrm{Na}_{2} \mathrm{Cr}_{2} \mathrm{O}_{7}$ of analytical-grade chemicals through weighting and dissolution in water. The standard colorimetric method for $\mathrm{Cr}(\mathrm{VI})$ measurement was performed as described previously [3]. Briefly, the solution containing $\mathrm{Cr}(\mathrm{VI})$ was mixed with $0.25 \%$ S-diphenylcarbazide and $6 \mathrm{M} \mathrm{H}_{2} \mathrm{SO}_{4}$ and was determined at $540 \mathrm{~nm}$ using a UV-Vis spectrophotometer (Thermo Fisher Scientific Inc., Waltham, MA, USA). To perform the BOD 5 analysis, the standard BOD method $5210 \mathrm{~B}$ was adopted. ORP, $\mathrm{pH}$, and DO were measured using a multiparameter portable meter 3630 IDS (Xylem Analytics, Beverly, MA, USA).

To understand the changes in the bacterial community of the three-stage SCMFC system, the biofilm at the anode was collected and analyzed. Bacterial DNA was extracted using a Fast DNA Spin Kit (MP Biomedicals, Santa Ana, CA, USA). Polymerase chain reaction (PCR) was performed to amplify the V3-V4 region of the eubacterial 16S ribosomal RNA fragments, and PCR profiling was performed as described previously [7]. The PCR-amplified 16S rRNA gene fragments were purified and preprocessed based on the methods described by Naz et al. (2016) [25]. The 16S rRNA gene sequence data were analyzed using QIIME software (version 1.17). After processing, the qualified reads were clustered into operational taxonomic units at a $97 \%$ sequence similarity through the UCLUST method [26]. Taxonomic assignment was performed on representative sequences using the RPD classifier. 
The SCMFC voltage was measured using a multimeter (Model 2700, Keithley Instruments, Inc., Solon, $\mathrm{OH}, \mathrm{USA}$ ) and recorded by a personal computer through a data acquisition system (Testpoint, Capital Equipment Co., Richmond, VA, USA). The current (I, amp) was obtained by dividing the resistance $(R, \mathrm{ohm})$ by the measured voltage $(V$, volt). The power $(P)$ was calculated as $P($ watt $)=I(\mathrm{amp}) \times V$ (volt). Power density and current density were measured as watts and amperes per unit of the total surface area of the anode.

\section{Results and Discussion}

\subsection{Effect of External Resistance on SCMFC Performance in Batch Operation}

When the potential of the SCMFC reached a steady state (after 19-21 days of immobilization operation), the biofilm in the anode was considered stable or mature [3]. To optimize the SCMFC biosensor's signal and performance, the effects of external resistance on the biosensor in batch operation were first evaluated. Figure 2 presents the curves of polarization and power density obtained in an SCMFC biosensor during the stable phase of power generation. Results revealed that the voltage of the SCMFC decreased with increasing current density and exhibited a typical polarization curve [27]. A maximum voltage of $926 \pm 32.5 \mathrm{mV}$ occurred at 10,000 $\Omega$. For voltage output to stabilize, $20-30 \mathrm{~min}$ was required. In addition, the power density of the SCMFC initially increased with current density but started to decrease after a certain point. The maximum power density was $167.5 \pm 6.8 \mathrm{~mW} / \mathrm{m}^{2}$; the voltage and external resistance were $367.2 \pm 42.5 \mathrm{mV}$ and $500 \Omega$, respectively, under such conditions. Therefore, the external resistance for each MFC within the SCMFC was set at $500 \Omega$ for subsequent experiments [27]. The maximum power density of the SCMFC is superior to that reported in earlier studies $\left(100.1 \pm 1.2 \mathrm{~mW} / \mathrm{m}^{2}\right)$ using a dual-chambered MFC inoculated with the same strain [7].

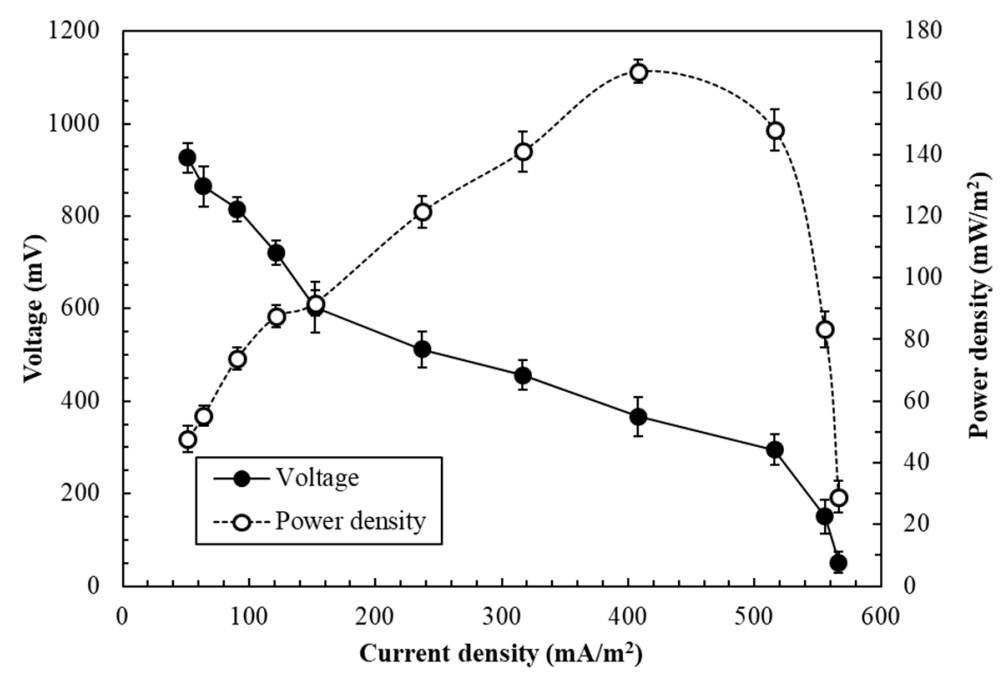

Figure 2. Curves of polarization and power density obtained in an SCMFC biosensor inoculated with E. aestuarii YC211 in the batch operation (anolyte: 1/1000 TSB supplemented with $60 \mathrm{mg} / \mathrm{L} \mathrm{Cr}(\mathrm{VI})$, external resistance: $50-10,000 \Omega$ ).

\subsection{Effect of $\mathrm{Cr}(V I)$ Concentration on SCMFC Performance in Batch Operation}

Wu et al. (2017) demonstrated that the performance of a dual-chambered MFC inoculated with E. aestuarii YC211 was not notably affected by water quality measurements (coexisting ions, $\mathrm{pH}$, or $\mathrm{NaCl}$ concentration) [7]. Therefore, the effect of $\mathrm{Cr}(\mathrm{VI})$ concentration on SCMFC performance in batch operation was evaluated. Under optimal operating conditions, the relationship between the $\mathrm{Cr}(\mathrm{VI})$ concentration and voltage output of the SCMFC was characterized. In this study, a response time of $20 \mathrm{~min}$ was required to obtain a stable voltage at $500 \Omega$. Figure 3 indicates that a negative correlation was observed for $\mathrm{Cr}(\mathrm{VI})$ concentrations ranging from 0.5 to $60 \mathrm{mg} / \mathrm{L}$. When the $\mathrm{Cr}(\mathrm{VI})$ 
concentration was lower than $0.5 \mathrm{mg} / \mathrm{L}$ or higher than $60 \mathrm{mg} / \mathrm{L}$, no linear relationship was observed. The regression equation for $\mathrm{Cr}(\mathrm{VI})$ concentration and voltage output of the SCMFC biosensor was determined to be $y=-5.7668 x+656.09\left(r^{2}=0.9997\right)$. Wu et al. (2017) using a dual-chambered MFC inoculated with YC211 also observed a linear relationship $(y=-2.3256 x+517.15)$, but their $\mathrm{Cr}(\mathrm{VI})$ concentration ranges narrowed down to $2.5-60 \mathrm{mg} / \mathrm{L}$. The higher slope or voltage drop that occurred in our SCMFC suggests the biosensor exhibits some competitive advantages compared with the dual-chambered MFC because of the SCMFC's relative sensitivity and wide measurement range.

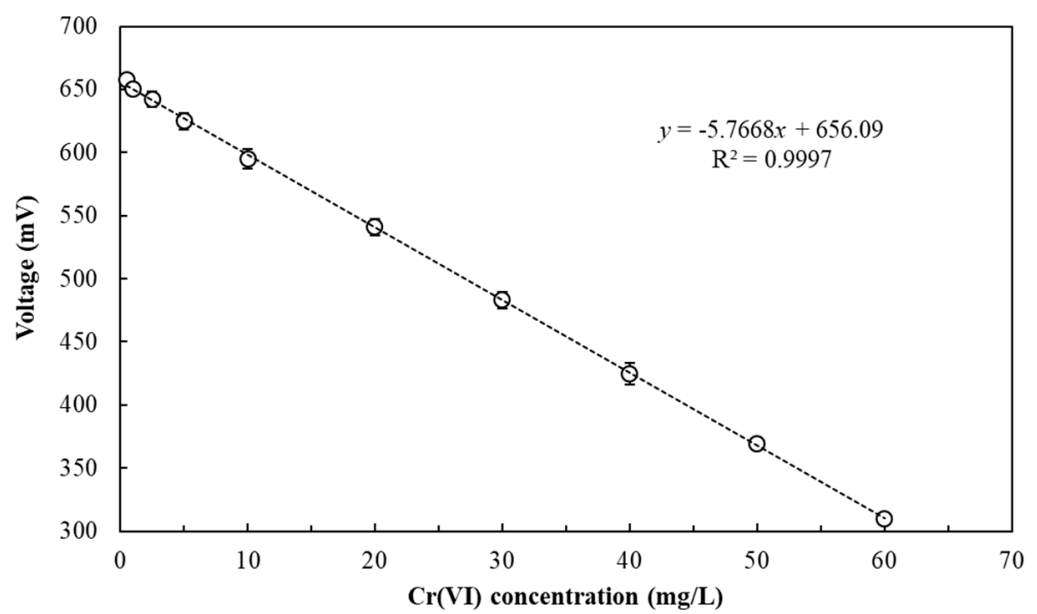

Figure 3. Relationship between $\mathrm{Cr}(\mathrm{VI})$ concentration and voltage output of the SCMFC biosensor inoculated with E. aestuarii YC211 in the batch operation (anolyte: 1/1000 TSB supplemented with different $\mathrm{Cr}(\mathrm{VI})$ concentrations, response time: $20 \mathrm{~min}$, external resistance: $500 \Omega$ ).

\subsection{Effect of Flowrate and Cr(VI) Concentration on the Stable Time of SCMFC Performance in Continuous-Flow Operation}

Based on practical application, an SCMFC biosensor should be developed for the in situ or real-time measurement of a wide range of $\mathrm{Cr}(\mathrm{VI})$ concentrations. Thus, the biosensor should be in continuous-flow operation. Figure $4 \mathrm{~A}$ indicates that the stable time for the potential production of the SCMFC shortens with an increasing retention time. A fast flowrate resulted in an evidently long stable time. The 2-min LRT achieved a relatively stable time (322 s) for potential production of the SCMFC. Thus, the retention time of the SCMFC was set at $2 \mathrm{~min}$ in continuous-flow operation during the subsequent experiment. Figure 4B illustrates the relationship between $\mathrm{Cr}(\mathrm{VI})$ concentration and stable time at 2 min of LRT. Results indicated that the stable time for potential production of the SCMFC increased with $\mathrm{Cr}(\mathrm{VI})$ concentration in continuous-flow operation. For 5-30 mg/L inlet Cr(VI) concentrations, 198-400 s of stable time was required. When $\mathrm{Cr}(\mathrm{VI})$ concentration was lower than $5 \mathrm{mg} / \mathrm{L}$ or higher than $30 \mathrm{mg} / \mathrm{L}$, the linear relationship did not apply.

\subsection{Establishment of a Standard Curve for Determination of Cr(VI) Concentration by the SCMFC in Continuous-Flow Operation}

To establish the standard curve for determination of $\mathrm{Cr}(\mathrm{VI})$ concentration by the SCMFC, different $\mathrm{Cr}(\mathrm{VI})$ concentrations were sequentially fed to the SCMFC at 2-min LRTs in continuous-flow operation. For the initial $3 \mathrm{~min}$, the anolyte was fed into the SCMFC, and the voltage output of the SCMFC reached $728 \pm 16.2 \mathrm{mV}$. After $3 \mathrm{~min}$, the anolyte containing $5 \mathrm{mg} / \mathrm{L} \mathrm{Cr}(\mathrm{VI})$ was fed, and the voltage output gradually decreased and stabilized at $645 \pm 9.2 \mathrm{mV}$ from minutes 7-11. After $11 \mathrm{~min}$, the voltage gradually recovered to $721 \pm 21.6 \mathrm{mV}$. When the anolyte containing $10 \mathrm{mg} / \mathrm{L} \mathrm{Cr}(\mathrm{VI})$ was fed, the voltage gradually decreased and stabilized at $624 \pm 6.1 \mathrm{mV}$ during minutes 16-19. After $19 \mathrm{~min}$, the anolyte containing $15 \mathrm{mg} / \mathrm{L} \mathrm{Cr}$ (VI) was fed, and the voltage output gradually decreased and stabilized at $602 \pm 5.1 \mathrm{mV}$ during minutes 25-27. A similar variation and tendency was observed after subsequent 
tests (Figure 5A). When $30 \mathrm{mg} / \mathrm{L} \mathrm{Cr}(\mathrm{VI})$ was fed, the voltage output steadily decreased to $537 \pm 4.6 \mathrm{mV}$. In this study, the stable times for various $\mathrm{Cr}(\mathrm{VI})$ concentrations were $3.3-6.6 \mathrm{~min}$.
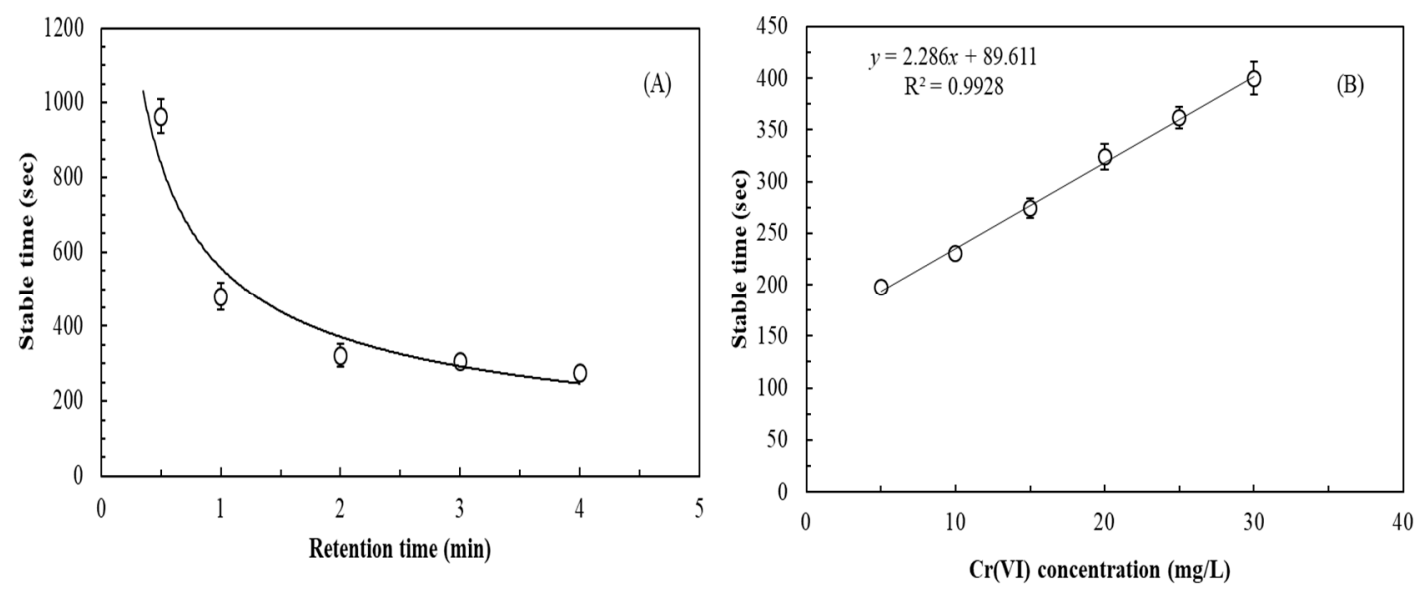

Figure 4. Effects of (A) retention time (anolyte: 1/1000 TSB supplemented with $20 \mathrm{mg} / \mathrm{L} \mathrm{Cr}(\mathrm{VI})$, external resistance: $500 \Omega$ ); (B) Cr(VI) concentration (anolyte: 1/1000 TSB supplemented with different $\mathrm{Cr}(\mathrm{VI})$ concentrations, liquid retention time: $2 \mathrm{~min}$, external resistance: $500 \Omega$ ) on the stable time of the SCMFC biosensor inoculated with E. aestuarii YC211 in the continuous-flow operation.
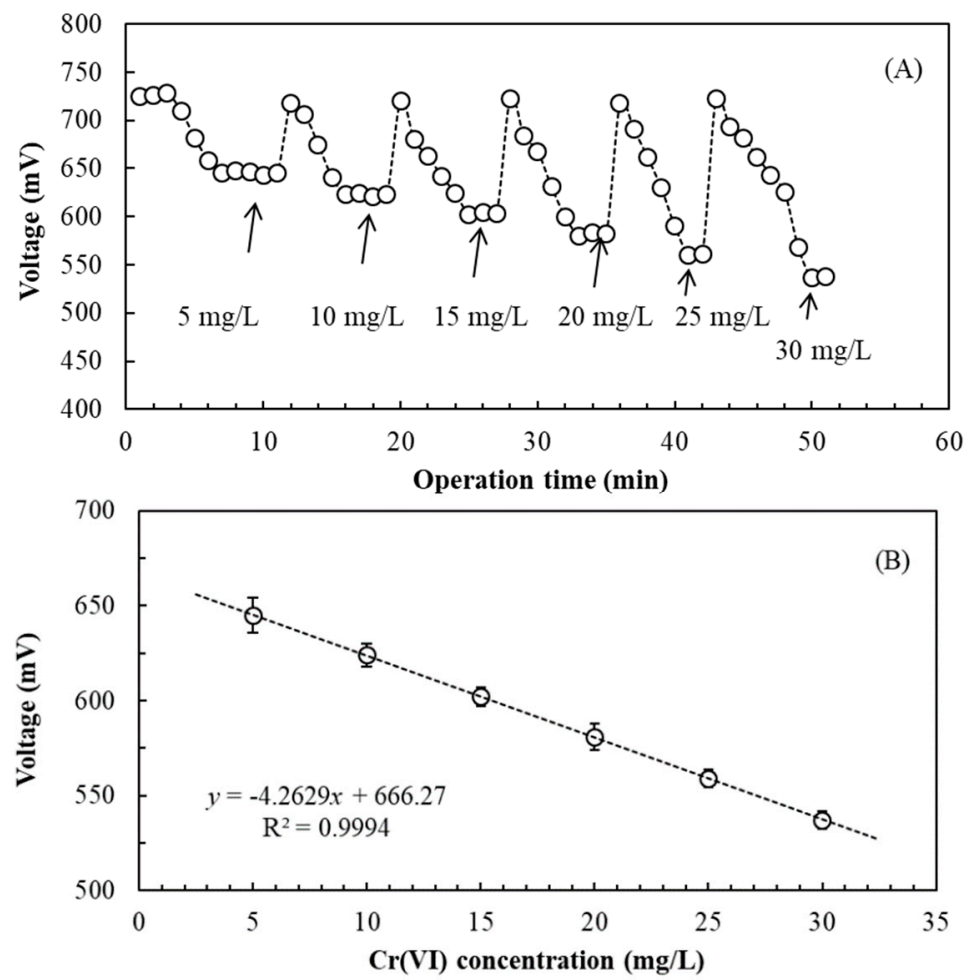

Figure 5. (A) Effect of different inlet $\mathrm{Cr}(\mathrm{VI})$ concentrations on voltage output of the SCMFC biosensor inoculated with E. aestuarii YC211 in the continuous-flow operation (liquid retention time: $2 \mathrm{~min}$, external resistance: $500 \Omega$ ); (B) Relationship between $\mathrm{Cr}(\mathrm{VI})$ concentration and voltage output of the SCMFC biosensor inoculated with E. aestuarii YC211 in the continuous-flow operation (voltage data obtained by 6.6-min stable time).

Figure $5 \mathrm{~B}$ shows the standard curve for the determination of $\mathrm{Cr}(\mathrm{VI})$ concentration by the SCMFC with 2-min LRT in continuous-flow operation. A strong negative correlation was observed between $\mathrm{Cr}(\mathrm{VI})$ concentrations and voltage output. The regression equation was determined to be $y$ (voltage, $\mathrm{mV})=-4.2629 x[\mathrm{Cr}(\mathrm{VI})$ concentration, $\mathrm{mg} / \mathrm{L}]+666.27\left(r^{2}=0.9994\right)$ when $\mathrm{Cr}(\mathrm{VI})$ concentration ranged 
from $5-30 \mathrm{mg} / \mathrm{L}$. Thus, using the standard curve, the $\mathrm{Cr}(\mathrm{VI})$ concentration in the wastewater can be determined in 6.6 min using an SCMFC biosensor in continuous-flow operation. Compared with the previous results of batch operation (Section 3.2), the range measurement of $\mathrm{Cr}(\mathrm{VI})$ concentration by the SCMFC is narrower in continuous-flow operation. Currently, no published studies exist regarding the continuous $\mathrm{Cr}(\mathrm{VI})$ measurement by MFC biosensors. Compared with previous studies using different MFC biosensors in batch operation, the measuring ranges of $2.5-60 \mathrm{mg} / \mathrm{L}$ by Wu et al. [7], $0.0125-5 \mathrm{mg} / \mathrm{L}$ by Wang et al. [10], $0.2-0.7 \mathrm{mg} / \mathrm{L}$ by Zhao et al. [20], $1-8 \mathrm{mg} / \mathrm{L}$ by Liu et al. [21], and $5-20 \mathrm{mg} / \mathrm{L}$ by $\mathrm{Xu}$ et al. [22] strongly suggest that the SCMFC biosensor has considerable potential for $\mathrm{Cr}(\mathrm{VI})$ measurement because of its wide dynamic range and continuous measurement.

\subsection{Cr(VI) Measurement of Artificial Tannery Wastewater Using Three-Stage SCMFC Biosensor in Continuous-Flow Operation}

The SCMFC biosensor could accurately determine $5-30 \mathrm{mg} / \mathrm{L}$ of $\mathrm{Cr}(\mathrm{VI})$ at 2-min LRT in continuous-flow operation. To expand the $\mathrm{Cr}(\mathrm{VI})$ measurement range, a three-stage SCMFC biosensor or system (Figure 1) was developed to determine the $\mathrm{Cr}(\mathrm{VI})$ concentration from artificial and actual tannery wastewater. Figure 6 presents the effect of $\mathrm{Cr}(\mathrm{VI})$ concentrations sequentially fed to the system on the voltage output of the SCMFC. In the first stage (through $14 \mathrm{~min}$ ), the initial voltage in MFC 1 was $725 \pm 10.5 \mathrm{mV}$; it gradually decreased and stabilized at $536.5 \pm 2.8 \mathrm{mV}$ between 6.6 and $10 \mathrm{~min}$ while $45 \mathrm{mg} / \mathrm{L} \mathrm{Cr}(\mathrm{VI})$ was introduced. The voltage output $(536.5 \mathrm{mV}$ ) of MFC 1 converted to $\mathrm{Cr}(\mathrm{VI})$ concentration in artificial tannery wastewater was $30.44 \mathrm{mg} / \mathrm{L}$ according to the regression equation presented in Figure 5B. After 3 min of operation, MFC 2 received the wastewater from MFC 1, and the voltage in MFC 2 gradually decreased before leveling off at $606.5 \pm 5.1 \mathrm{mV}$ during minutes 7-13. The $\mathrm{Cr}(\mathrm{VI})$ concentration in the artificial tannery wastewater was calculated as $14.02 \mathrm{mg} / \mathrm{L}$. After $4 \mathrm{~min}$, the MFC 2 effluent flowed into MFC 3; the lack of voltage change indicated a zero $\mathrm{Cr}(\mathrm{VI})$ concentration. Therefore, the inflow $\mathrm{Cr}(\mathrm{VI})$ concentration was reduced in the three-stage SCMFC biosensor, and the value was $44.46(30.44+14.02) \mathrm{mg} / \mathrm{L}$.

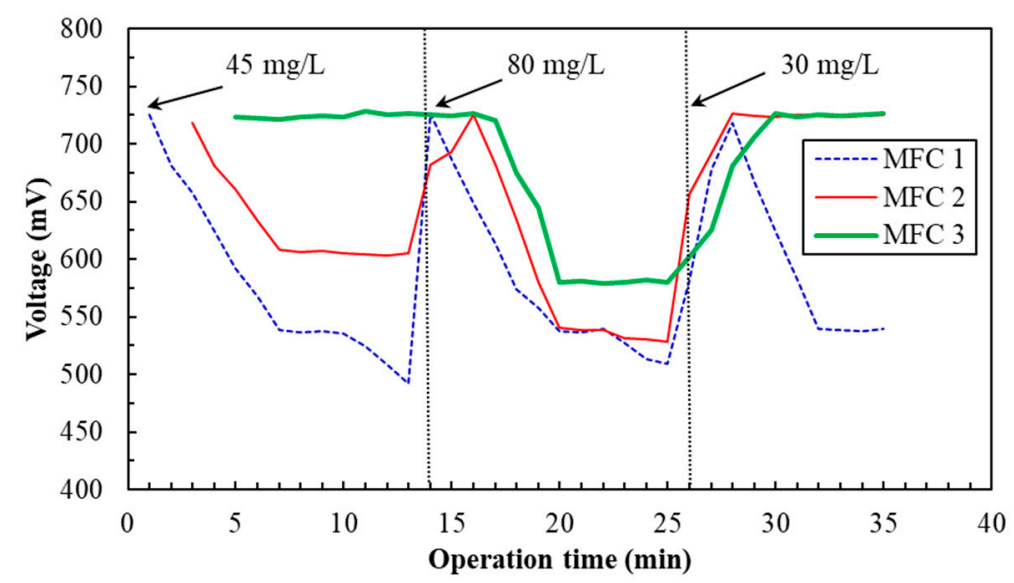

Figure 6. Effect of $\mathrm{Cr}(\mathrm{VI})$ concentrations sequentially fed to the system on the voltage output of the three-stage SCMFC biosensor inoculated with E. aestuarii YC211 in continuous-flow operation (liquid retention time: $2 \mathrm{~min}$, stable time: $6.6 \mathrm{~min}$, external resistance: $500 \Omega$ ).

In the second stage (14th-26th min), the voltage $(726 \pm 12.8 \mathrm{mV})$ in MFC 1 gradually decreased and stabilized at $537.3 \pm 1.4 \mathrm{mV}$ during minutes $20-22$, while $80 \mathrm{mg} / \mathrm{L} \mathrm{Cr}(\mathrm{VI})$ was introduced. $\mathrm{The} \mathrm{Cr}(\mathrm{VI})$ concentration in artificial tannery wastewater was calculated as $30.25 \mathrm{mg} / \mathrm{L}$. MFC 2 received the MFC 1 effluent, and the voltage in MFC2 gradually decreased before leveling off at $539.0 \pm 1.2 \mathrm{mV}$ during minutes 20-22. The $\mathrm{Cr}(\mathrm{VI})$ concentration in artificial tannery wastewater was calculated as $29.86 \mathrm{mg} / \mathrm{L}$. Finally, the MFC 2 effluent flowed into MFC 3, and the voltage in MFC 3 stabilized at $580.0 \pm 5.3 \mathrm{mV}$ during minutes $20-25$. The $\mathrm{Cr}(\mathrm{VI})$ concentration in wastewater was calculated as $20.24 \mathrm{mg} / \mathrm{L}$. Thus, 
the inflow $\mathrm{Cr}(\mathrm{VI})$ concentration was reduced in the three-stage SCMFC biosensor, and its value was $80.35(30.25+29.86+20.24) \mathrm{mg} / \mathrm{L}$.

In the third stage (26th-35th $\mathrm{min}$ ), the voltage in MFC 1 first rose to $718 \pm 18.2 \mathrm{mV}$ and stabilized at $538.5 \pm 0.6 \mathrm{mV}$ during minutes $32-35$ while $30 \mathrm{mg} / \mathrm{L} \mathrm{Cr}(\mathrm{VI})$ was introduced. $\mathrm{The} \mathrm{Cr}(\mathrm{VI})$ concentration in wastewater was calculated as $29.97 \mathrm{mg} / \mathrm{L}$. After $30 \mathrm{~min}$ of operation, the voltages in MFC 2 and MFC 3 remained at $725.6 \pm 13.4 \mathrm{mV}$, suggesting that $\mathrm{Cr}(\mathrm{VI})$ did not exist in the wastewater. Therefore, the inflow $\mathrm{Cr}(\mathrm{VI})$ concentration was reduced in the three-stage SCMFC biosensor, and its value was $29.97 \mathrm{mg} / \mathrm{L}$. The results indicated deviations were $-1.2 \%, 0.44 \%$, and $-0.09 \%$ for determining 45,80 , and $30 \mathrm{mg} / \mathrm{L} \mathrm{Cr}(\mathrm{VI})$, respectively, using the three-stage SCMFC biosensor.

\subsection{Cr(VI) Measurement of Actual Tannery Wastewater Using Three-Stage SCMFC Biosensor and Bacterial Community in Three-Stage SCMFC Biosensor in Continuous-Flow Operation}

The three-stage SCMFC biosensor exhibited low deviations in the range of $-1.2 \%$ to $0.44 \%$ in the $\mathrm{Cr}(\mathrm{VI})$ measurement from artificial tannery wastewater. However, the concentration and composition of organic compounds vary in actual tannery wastewater; therefore, the feasibility of the three-stage SCMFC biosensor for $\mathrm{Cr}(\mathrm{VI})$ measurement from an actual tannery wastewater should be evaluated. A previous study revealed that water quality parameters did not significantly affect the performance of an MFC inoculated with E. aestuarii YC211 [7]. Thus, this study focuses on the effect of crucial electron donors (e.g., organic compounds) and acceptors (e.g., $\mathrm{Cr}^{6+}, \mathrm{O}_{2}$ ) existing in the tannery wastewater. The mechanism for $\mathrm{Cr}(\mathrm{VI})$ measurement using the SCMFC biosensor inoculated with E. aestuarii YC211 is possibly as follows [10]:

$$
\begin{aligned}
& \text { Anode: Organics } \rightarrow \mathrm{CO}_{2} \text { (or other intermediates) }+\mathrm{H}^{+}+\mathrm{e}^{-} \text {(by E. aestuarii } \mathrm{YC211} \text { ) } \\
& \qquad \begin{array}{c}
\left.\mathrm{Cr}^{6+}+\mathrm{e}^{-} \rightarrow \mathrm{Cr}^{3+} \text { (by E. aestuarii } \mathrm{YC211}\right) \\
\mathrm{O}_{2}+\mathrm{H}^{+}+\mathrm{e}^{-} \rightarrow \mathrm{H}_{2} \mathrm{O} \text { (by chemical reaction) } \\
\text { Cathode: } \mathrm{O}_{2}+\mathrm{H}^{+}+\mathrm{e}^{-} \rightarrow \mathrm{H}_{2} \mathrm{O} \text { (by chemical reaction) }
\end{array}
\end{aligned}
$$

The higher the organic concentrations entering the SCMFC are, the greater the voltages are produced. The higher the $\mathrm{Cr}^{6+}$ or $\mathrm{O}_{2}$ concentrations are in the anode, the fewer electrons are transferred to the cathode, and the fewer voltages are produced. Thus, the potential output will decrease with increasing $\mathrm{Cr}^{6+}$ concentration except in a case of $\mathrm{O}_{2}$ interference. According to the result in Figure $5 \mathrm{~B}$, the SCMFC biosensor for $\mathrm{Cr}(\mathrm{VI})$ measurement range is $5-30 \mathrm{mg} / \mathrm{L}$; therefore, the theoretical $\mathrm{Cr}(\mathrm{VI})$ measurement range of the three-stage SCMFC biosensor would be extended to $5-90 \mathrm{mg} / \mathrm{L}$ by cumulating its voltage [23]. Table 1 lists $\mathrm{Cr}(\mathrm{VI})$ measurements of the effluents of eight leather processing units (A-H) by three-stage SCMFC biosensor in continuous-flow operation and using colorimetric method in batch operation. Results indicated a higher deviation $(>12 \%)$ in the $\mathrm{Cr}(\mathrm{VI})$ measurement of effluents of units $\mathrm{A}$ and $\mathrm{H}(2.6$ and $124.5 \mathrm{mg} / \mathrm{L}$ ) by our system compared with the colorimetric method. This can be explained by the fact that the measurement range was not within the optimal 5-90 mg/L measurement range. A lower deviation $(<7 \%)$ was observed in $\mathrm{Cr}(\mathrm{VI})$ measurement from effluents of units B-G $(6.8-84.2 \mathrm{mg} / \mathrm{L})$ by our system compared with the colorimetric method because these units' concentrations fell in the measurement range. Compared with the deviation $(-1.2 \%-0.44 \%)$ of $\mathrm{Cr}(\mathrm{VI})$ measurement of artificial wastewater using a similar system (Figure 6), $\mathrm{Cr}(\mathrm{VI})$ measurement of actual wastewater is less accurate, mainly because of the effects of BOD and DO in the wastewater [28]. 
If the inlet organic concentration of BOD in the wastewater was $>256 \mathrm{mg} / \mathrm{L}$ (the anolyte as BOD), the initial potential of the three-stage SCMFC system would be higher than the expected value. Although the amplitude of the voltage drop of the SCMFC was identical at the same $\mathrm{Cr}(\mathrm{VI})$ concentration, the stable voltage was higher than the theoretical voltage. Thus, the $\mathrm{Cr}(\mathrm{VI})$ concentration was underestimated according to the standard curve and resulted in a negative deviation (for units $\mathrm{B}$, C, D, and E). Conversely, BOD in the wastewater was $<256 \mathrm{mg} / \mathrm{L}$, which resulted in a lower initial potential than the expected value. At the same potential drop, the voltage value at the equilibrium would be lower than the theoretical voltage. Thus, the $\mathrm{Cr}(\mathrm{VI})$ concentration was overestimated and resulted in a positive deviation (units $\mathrm{F}$ and $\mathrm{G}$ ). In addition, high $\mathrm{DO}$ content competes with $\mathrm{Cr}(\mathrm{VI})$ as an electron acceptor and causes the potential drop of the non-Cr(VI) factor. This resulted in the $\mathrm{Cr}(\mathrm{VI})$ concentration being overestimated with a positive deviation (unit F). However, a combination effect (DO and organics) is possible in this system [28].

Table 1. $\mathrm{Cr}(\mathrm{VI})$ measurement from effluents of eight leather processing units by three-stage SCMFC biosensor in continuous-flow operation and colorimetric method in batch operation.

\begin{tabular}{|c|c|c|c|c|c|c|c|c|}
\hline \multicolumn{9}{|c|}{ Tannery Wastewater } \\
\hline Unit & $\mathbf{A}$ & B & C & D & $\mathbf{E}$ & $\mathbf{F}$ & G & $\mathbf{H}$ \\
\hline BOD & 250 & 350 & 360 & 420 & 460 & 180 & 230 & 560 \\
\hline DO & 2.1 & 1.8 & 2.3 & 2.6 & 2.5 & 3.1 & 1.6 & 1.2 \\
\hline MFC biosensor & $2.6 \pm 0.08$ & $6.8 \pm 0.21$ & $12.8 \pm 0.51$ & $32.4 \pm 2.01$ & $52.3 \pm 1.62$ & $75.6 \pm 2.41$ & $84.2 \pm 3.64$ & $124.5 \pm 7.26$ \\
\hline $\begin{array}{c}\text { Colorimetric } \\
\text { method }\end{array}$ & $2.3 \pm 0.04$ & $7.1 \pm 0.13$ & $13.6 \pm 0.35$ & $33.6 \pm 1.06$ & $56.1 \pm 1.81$ & $71.2 \pm 2.56$ & $82.6 \pm 4.06$ & $142.1 \pm 6.04$ \\
\hline Deviation $(\%)^{*}$ & $13.0 \%$ & $-4.2 \%$ & $-5.9 \%$ & $-3.6 \%$ & $-6.8 \%$ & $6.2 \%$ & $1.9 \%$ & $-12.4 \%$ \\
\hline
\end{tabular}

To understand the changes in the bacterial community of the three-stage SCMFC biosensor after operation, the biofilm at the anode was analyzed through NGS [29]. Figure 7 indicates the relative abundances of the bacterial 16S rRNA gene sequences in three separate SCMFCs (MFC 1, MFC 2, and MFC 3) after measuring the $\mathrm{Cr}(\mathrm{VI})$ concentration from the effluents of eight leather processing units. At first, E. aestuarii YC211 alone was inoculated in the three-stage SCMFC. After the SCMFC system was used to treat the wastewater, the bacterial community in MFC 1 was the simplest, and only four strains were observed: E. aestuarii (97.5\%), O. anthropi (1.45\%), Exiguobacterium sp. $(0.92 \%)$, and $O$. tritici $(0.13 \%)$. These four strains are classified as $\mathrm{Cr}(\mathrm{VI})$-reducing bacteria $[7,10,30,31]$; thus, they can endure relatively high $\mathrm{Cr}(\mathrm{VI})$ concentrations. The complexity of the bacterial community in MFC 2 was the second simplest, and the community increased to seven strains. The strains included Lysinibacillus fusiformis, Pseudomonas putida, and Arthrobacter sp. in addition to the four strains that existed in MFC 1. The $\mathrm{Cr}(\mathrm{VI})$-reducing capability of these three strains has been reported [32-34]. In MFC2, the dominant strain remained E. aestuarii (95.12\%), and other strains were represented at $<1.5 \%$. The bacterial community in MFC 3 was the most complicated because the inlet $\mathrm{Cr}(\mathrm{VI})$ concentration was the lowest. The bacterial community increased to 10 strains. The strains comprised Microbacterium sp., Streptomyces coelicolor, and Staphylococcus aureus and the seven strains that existed in MFC 2. These three new strains have been regarded as potential $\mathrm{Cr}(\mathrm{VI})$-reducing bacteria $[4,35,36]$. In MFC 3, the dominant strain was E. aestuarii (92.54\%), and other strains were represented at $<3.0 \%$. The results of the aforementioned studies demonstrate that reliable three-stage SCMFC performance ( $<7 \%$ deviation) should be attributed to a stable bacterial community ( $>92.5 \%$ original strains) present during the treatment period (four months). 


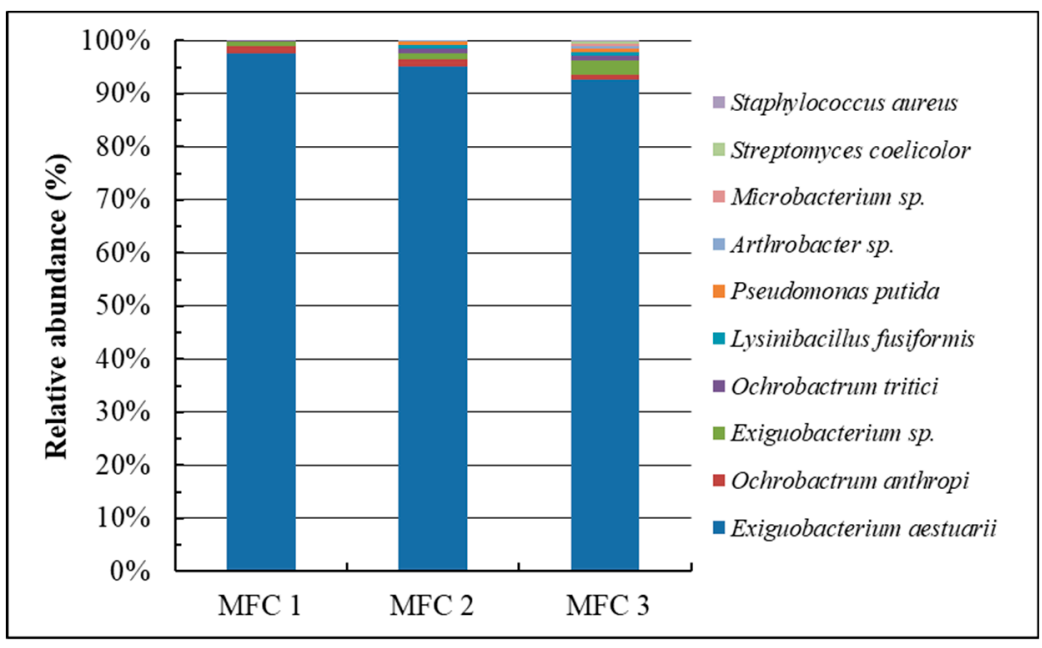

Figure 7. Relative abundances of the bacterial $16 \mathrm{~S}$ rRNA gene sequences in the biofilm of three-stage SCMFC biosensor after measuring the $\mathrm{Cr}(\mathrm{VI})$ concentration from the effluents of eight leather processing units.

\section{Conclusions}

In this study, a three-stage SCMFC biosensor inoculated with E. aestuarii YC211 was developed for the continuous measurement of $\mathrm{Cr}(\mathrm{VI})$ from actual tannery wastewater. The system exhibits competitive advantages over previous MFCs, including a simpler structure, higher accuracy, shorter measurement time, and wider measurement range. Through NGS analysis, the original inoculated E. aestuarii remained dominant $(92.5 \%-97.5 \%$ of the total bacterial community) in the three-stage SCMFC even after treating the actual tannery wastewater. The parameters most affecting the accurate $\mathrm{Cr}(\mathrm{VI})$ measurement of the system were the concentrations of organics and oxygen in the wastewater. Although both these unexpected factors may slightly restrict the system's application, the system has a potential as an early warning device with wide dynamic range for in situ, real-time, and continuous $\mathrm{Cr}(\mathrm{VI})$ measurement. Moreover, the three-stage SCMFC can further expand to a multistage MFC biosensor by connecting several separate SCMFCs in series and increase its application fields or range.

Author Contributions: All authors collaborated to carry out the work presented here. Y.-C.C., L.-C.W. and G.-H.W. conceived and designed the experiments; G.-H.W. and T.-H.T. performed the experiments; S.-Y.L. and C.-Y.C. analyzed the data; Y.-C.C. wrote the paper; Y.-C.C. and L.-C.W. reviewed and edited the manuscript. All authors read and approved the manuscript.

Funding: This research was funded by MOST 104-2313-B-157-001-MY3 and MOST 107-2313-B-157-001-MY2.

Conflicts of Interest: The authors declare no conflict of interest.

\section{References}

1. Rahman, A.; Nahar, N.; Nawani, N.N.; Jass, J.; Hossain, K.; Saud, Z.A.; Saha, A.K.; Ghosh, S.; Olsson, B.; Mandal, A. Bioremediation of hexavalent chromium (VI) by a soil-borne bacterium, Enterobacter cloacae B2-DHA. J. Environ. Sci. Health Part A 2015, 50, 1136-1147. [CrossRef] [PubMed]

2. Joutey, N.T.; Sayel, H.; Bahafid, W.E.; Ghachtouli, N. Mechanisms of hexavalent chromium resistance and removal by microorganisms. Rev. Environ. Contam. Toxicol. 2015, 233, 45-69.

3. Chen, C.Y.; Cheng, C.Y.; Chen, C.K.; Hsieh, M.C.; Lin, S.T.; Ho, K.Y.; Li, J.W.; Lin, C.P.; Chung, Y.C. Hexavalent chromium removal and bioelectricity generation by Ochrobactrum sp. YC211 under different oxygen conditions. J. Environ. Sci. Health Part A 2014, 51, 502-508. [CrossRef]

4. Lun, L.; Li, D.; Yin, Y.; Li, D.; Xu, G.; Zhao, Z.; Li, S. Characterization of chromium waste form based on biocementation by Microbacterium sp. GM-1. Indian J. Microbiol. 2016, 56, 353-360. [CrossRef] [PubMed] 
5. Kang, C.; Wu, P.; Li, L.; Yu, L.; Ruan, B.; Gong, B.; Zhu, N. Cr(VI) reduction and Cr(III) immobilization by resting cells of Pseudomonas aeruginosa CCTCC AB93066: Spectroscopic, microscopic, and mass balance analysis. Environ. Sci. Pollut. Res. Int. 2017, 24, 5949-5963. [CrossRef] [PubMed]

6. Li, J.; Guo, W.; Shi, M.; Cao, Y.; Wang, G. High-quality-draft genomic sequence of Paenibacillus ferrarius $C Y 1^{\mathrm{T}}$ with the potential to bioremediate Cd, Cr and Se contamination. Stand. Genom. Sci. 2017, 12, 60. [CrossRef] [PubMed]

7. Wu, L.C.; Tsai, T.H.; Liu, M.H.; Kuo, J.L.; Chang, Y.C.; Chung, Y.C. A Green microbial fuel cell-based biosensor for in situ chromium (VI) measurement in electroplating wastewater. Sensors 2017, 17, 2461. [CrossRef]

8. Baldiris, R.; Acosta-Tapia, N.; Montes, A.; Hernández, J.; Vivas-Reyes, R. Reduction of hexavalent chromium and detection of chromate reductase (ChrR) in Stenotrophomonas maltophilia. Molecules 2018, $23,406$. [CrossRef]

9. Jobby, R.; Jha, P.; Yadav, A.K.; Desai, N. Biosorption and biotransformation of hexavalent chromium [Cr(VI)]: A comprehensive review. Chemosphere 2018, 207, 255-266. [CrossRef]

10. Wang, G.H.; Cheng, C.Y.; Liu, M.H.; Chen, T.Y.; Hsieh, M.C.; Chung, Y.C. Utility of Ochrobactrum anthropi YC152 in a microbial fuel cell as an early warning device for hexavalent chromium determination. Sensors 2016, 16, 1272. [CrossRef]

11. Coelho, C.; Branco, R.; Natal-da-Luz, T.; Sousa, J.P.; Morais, P.V. Evaluation of bacterial biosensors to determine chromate bioavailability and to assess ecotoxicity of soils. Chemosphere 2015, 128, 62-69. [CrossRef] [PubMed]

12. Gurung, A.; Oh, S.; Kim, K.D.; Shin, B. Semi-continuous detection of toxic hexavalent chromium using a sulfur-oxidizing bacteria biosensor. J. Environ. Manag. 2012, 106, 110-112. [CrossRef] [PubMed]

13. Bohrn, U.; Mucha, A.; Werner, C.F.; Trattner, B.; Backer, M.; Krumbe, C.; Schienle, M.; Stutz, E.; Schmitt-Landsiedel, D.; Fleischer, M. A critical comparison of cell-based sensor systems for the detection of $\mathrm{Cr}(\mathrm{VI})$ in aquatic environment. Sens. Actuators B Chem. 2013, 182, 58-65. [CrossRef]

14. Panda, J.; Sarkar, P. Biosensing and bioremediation of $\mathrm{Cr}(\mathrm{VI})$ by cell free extract of Enterobacter aerogenes $\mathrm{T} 2$. J. Environ. Sci. Health Part A 2014, 49, 600-608. [CrossRef] [PubMed]

15. Biswas, P.; Karn, A.K.; Balasubramanian, P.; Kale, P.G. Biosensor for detection of dissolved chromium in potable water: A review. Biosens. Bioelectron. 2017, 94, 589-604. [CrossRef]

16. Kharkwal, S.; Tan, Y.C.; Lu, M.; Ng, H.Y. Development and Long-Term Stability of a Novel Microbial Fuel Cell BOD Sensor with $\mathrm{MnO}_{2}$ Catalyst. Int. J. Mol. Sci. 2017, 18, 276. [CrossRef]

17. Zhou, T.; Han, H.; Liu, P.; Xiong, J.; Tian, F.; Li, X. Microbial Fuels cell-based biosensor for toxicity detection: A review. Sensors 2017, 17, 2230. [CrossRef]

18. Wu, X.; Ren, X.; Owens, G.; Brunetti, G.; Zhou, J.; Yong, X.; Wei, P.; Jia, H. A facultative electroactive chromium (VI)-reducing bacterium aerobically isolated from a biocathode microbial fuel cell. Front. Microbiol. 2018, 9 , 2883. [CrossRef]

19. Ucar, D.; Zhang, Y.; Angelidaki, I. An overview of electron acceptors in microbial fuel cell. Front. Microbiol. 2017, 8, 643. [CrossRef]

20. Zhao, S.; Liu, P.; Niu, Y.; Chen, Z.; Khan, A.; Zhang, P.; Li, X. A novel early warning system based on a sediment microbial fuel cell for in situ and real time hexavalent chromium detection in industrial wastewater. Sensors 2018, 18, 642. [CrossRef]

21. Liu, B.; Lei, Y.; Li, B. A batch-mode cube microbial fuel cell based "shock" biosensor for wastewater quality monitoring. Biosens. Bioelectron. 2014, 62, 308-314. [CrossRef]

22. Xu, Z.; Liu, B.; Dong, Q.; Lei, Y.; Li, Y.; Ren, J.; McCutcheon, J.; Li, B. Flat microliter membrane-based microbial fuel cell as "on-line sticker sensor" for self-supported in situ monitoring of wastewater shocks. Bioresour. Technol. 2015, 197, 244-251. [CrossRef]

23. Spurr, M.W.A.; Yu, E.H.; Scottb, K.; Head, I.M. Extending the dynamic range of biochemical oxygen demand sensing with multi-stage microbial fuel cells. Environ. Sci. Water Res. Technol. 2018, 4, 2029-2040. [CrossRef]

24. Santoro, C.; Agrios, A.; Pasaogullari, U.; Li, B. Effects of gas diffusion layer (GDL) and micro porous layer (MPL) on cathode performance in microbial fuel cells (MFCs). Int. J. Hydrog. Energy 2011, 36, 13096-13104. [CrossRef]

25. Naz, I.; Hodgson, D.; Smith, A.; Marchesi, J.; Ahmed, S.; Avignone-Rossa, C.; Saroj, D.P. Effect of the chemical composition of filter media on the microbial community in wastewater biofilms at different temperatures. RSC Adv. 2016, 6, 104345-104353. [CrossRef] 
26. Edgar, R.C. Search and clustering orders of magnitude faster than BLAST. Bioinformatics 2010, 26, $2460-2461$. [CrossRef]

27. Oh, S.T.; Kim, J.R.; Premier, G.C.; Lee, T.H.; Kim, C.; Sloan, W.T. Sustainable wastewater treatment: How might microbial fuel cells contribute. Biotechnol. Adv. 2010, 28, 871-881. [CrossRef]

28. Li, M.; Zhou, M.; Tian, X.; Tan, C.; McDaniel, C.T.; Hassett, D.J.; Gu, T. Microbial fuel cell (MFC) power performance improvement through enhanced microbial electrogenicity. Biotechnol. Adv. 2018, 36, 1316-1327. [CrossRef]

29. Almeida, O.G.G.; De Martinis, E.C.P. Bioinformatics tools to assess metagenomic data for applied microbiology. Appl. Microbiol. Biotechnol. 2019, 103, 69-82. [CrossRef]

30. Alam, M.Z.; Malik, A. Chromate resistance, transport and bioreduction by Exiguobacterium sp. ZM-2 isolated from agricultural soil irrigated with tannery effluent. J. Basic Microbiol. 2008, 48, 416-420. [CrossRef]

31. Francisco, R.; de Abreu, P.; Plantz, B.A.; Schlegel, V.L.; Carvalho, R.A.; Morais, P.V. Metal-induced phosphate extracellular nanoparticulate formation in Ochrobactrum tritici 5bvl1. J. Hazard. Mater. 2011, 198, 31-39. [CrossRef]

32. Huang, J.; Li, J.; Wang, G. Production of a microcapsule agent of chromate-reducing Lysinibacillus fusiformis ZC1 and its application in remediation of chromate-spiked soil. SpringerPlus 2016, 5, 561. [CrossRef]

33. Viradia, S.H.; Vala, A.K. In silico protein structure modeling and conservation analysis of ChrR, a class-I chromate reducing flavoenzyme from Pseudomonas putida. Protein Pept. Lett. 2013, 20, 1049-1053. [CrossRef]

34. Field, E.K.; Blaskovich, J.P.; Peyton, B.M.; Gerlach, R. Carbon-dependent chromate toxicity mechanism in an environmental Arthrobacter isolate. J. Hazard. Mater. 2018, 355, 162-169. [CrossRef]

35. Gren, T.; Ostash, B.; Hrubskyy, Y.; Tistechok, S.; Fedorenko, V. Influence of transition metals on Streptomyces coelicolor and S. sioyaensis and generation of chromate-reducing mutants. Folia Microbiol. 2014, 59, 147-153. [CrossRef]

36. Ilias, M.; Rafiqullah, I.M.; Debnath, B.C.; Mannan, K.S.; Mozammel Hoq, M. Isolation and characterization of chromium (VI)-reducing bacteria from tannery effluents. Indian J. Microbiol. 2011, 51, 76-81. [CrossRef]

(C) 2019 by the authors. Licensee MDPI, Basel, Switzerland. This article is an open access article distributed under the terms and conditions of the Creative Commons Attribution (CC BY) license (http:/ / creativecommons.org/licenses/by/4.0/). 